\title{
Ebelik bölümü öğrencilerinin ve annelerinin kendi kendine meme muayenesi yapma durumları ve meme kanseri korkusu arasındaki ilişkinin belirlenmesi
} Determining the relationship between the breast self-examination of midwifery students and their mothers and fear
of breast cancer

\author{
Melek Şen Aytekin', (D) Öznur Çetin', (D) Ayşenur Kahraman'
}

${ }^{1}$ Tokat Gaziosmanpaşa Üniversitesi, Sağlık Bilimleri Fakültesi, Ebelik Bölümü, Tokat, Türkiye

\section{ÖZET}

Amaç: Bu araştırmada ebelik bölümü öğrencilerinin ve annelerinin Kendi Kendine Meme Muayenesi (KKMM) yapma durumları ve meme kanseri korkusu arasındaki ilişkinin belirlenmesi ve ebelik bölümü öğrencilerinin KKMM'yi etrafındaki kadınlara öğretme durumlarını belirlemek amacıyla yapılmıştır.

Yöntem: Bu çalışma, tanımlayıcı, ilişki arayıcı tiptedir. Araştırmanın evrenini Kadın Sağlığı ve Hastalıkları dersini alan 3. ve 4. sınıf ebelik bölümü öğrencileri ve öğrencilerin anneleri oluşturmuştur. Örneklemini ise evreni \%90 güven aralığı ve \pm 5 yanılma payı ile 164 kişi oluşturmaktadır. Araştırma gönüllü olarak katılmayı kabul eden 93 öğrenci ile 93 anne olmak üzere 186 kişi ile tamamlanmıştır. Veriler online olarak öğrencilere ve annelere yönelik olarak ayrı ayrı hazırlanan Kişisel Bilgi Formu I ve Kişisel Bilgi Formu II, Meme Kanseri Korkusu Ölçeği ile toplanmıştır. Verilerin analizinde SPSS 22,0 paket programı kullanılmıştır.

Bulgular: Araştırmaya katılan öğrencilerin yaş ortalaması $21.80 \pm 1.09$ yıl, \%54.8'i ebelik bölümü 3. sınıfta öğrenim görmektedir. Annelerin yaş ortalaması 48.59 \pm 5.69 yıldır, \%60.2'si ilkokul mezunu, \%91.4'ü evlidir. Çalışmada annelerin ölçekten aldığı puan ortalaması 25.75 \pm 7.28 , öğrencilerin ölçekten aldığı puan ortalaması $25.00 \pm 7.491$ 'dir. Öğrencilerin meme kanseri korkusu ölçeğinden aldıkları puan ile kendi kendine meme muayenesi yapma zamanı arasında anlamlı bir fark bulunmuştur $(p<0.05, \mathrm{~F}=2.770)$.

Sonuçlar: Annelerin ve öğrencilerin ölçekten aldıkları puan değerlendirildiğinde yüksek derecede meme kanseri korkusuna sahip oldukları belirlenmiştir.

Anahtar kelimeler: ebelik öğrencisi; kendi kendine meme muayenesi; korku; meme kanseri

\section{ABSTRACT}

Aim: This study was conducted to determine the relationship between midwifery department students and their mothers' BSE and fear of breast cancer, and to determine the midwifery department students' teaching status of BSE to women around them.

Methods: This study is descriptive, relationship-seeking type. 3rd and 4th grade midwifery students and their mothers who volunteered to participate in the study were included. The study was completed with 186 participants. Data were collected online with Personal Information Form I and Personal Information Form II, Breast Cancer Fear Scale, which were prepared semi-individually for students and mothers. SPSS 22.0 package program was used in the analysis of the data.

Results: The average age of the students participating in the research is $21.80 \pm 1.09$ years, $54.8 \%$ of them are studying in the 3 rd year of midwifery department. The mean age of the mothers was $48.59 \pm 5.69$ years, $60.2 \%$ were primary school graduates, and $91.4 \%$ were married. In the study, the mean score of the mothers from the scale was $25.75 \pm 7.28$, and the mean score of the students from the scale was $25.00 \pm 7.491$. A significant correlation was found between the breast cancer fear score of mothers and students and the time to perform breast self-examination $(p<0.05)$ $(\mathrm{F}=2.770)$.

Conclusion: When the scores of the mothers and students from the scale were evaluated, it was determined that they had a high level of fear of breast cancer.

Keywords: breast cancer; breast self-exam; fear; midwifery student

\section{Giriş}

Meme kanseri, memenin süt üreten bezlerinde veya meme uçlarına süt salgılayan kanallarda hücrelerin kontrolsüz büyümesi ile karakterize bir kanserdir (Birhane ve ark., 2017). Meme kanseri küresel çapta bir halk sağlığı sorunudur. Gelişmiş ve gelişmekte olan ülkelerde kadınlar arasında en yaygın kanserdir. Dünya çapında, her yıl 1,7 milyondan fazla meme kanseri vakası teşhis edilmekte ve her yıl 502.000 kadın meme kanseri nedeniyle hayatını kaybetmektedir (Abolfotouh ve ark., 2015; Nde, Assob, Kwenti, Njunda \& Tainenbe, 2015; Birhane ve ark., 2017). Oysa meme kanseri erken evrede tanı aldığında mortalite ve morbidite oranı düşmektedir.

Erken evrelerde meme kanseri teşhis edilirse tedavinin başarı şansı yüksektir. Ancak ileri evrelerde tedavi süreci maliyetli olmakta ve sonuçları genellikle olumsuz olarak karşımıza çıkmaktadır (Birhane ve ark., 2017). Meme kanserinin erken evrede tespit edilmesine yönelik bazı tarama yöntemleri mevcuttur. Bu yöntemler kendi kendine meme muayenesi (KKMM), klinik meme muayenesi (KMM) ve mamografiyi içermektedir (Abolfotouh ve ark., 2015; Nde ve ark., 2015). Kadınlar meme kanserinin erken teşhis ve tedavi fırsatını, meme kanserinin tanısına yönelik bilgi ve farkındalık eksikliği nedeniyle kaçırmaktadır (Abolfotouh ve ark., 2015). Literatürde yapılan çalışmalar bu bilgiyi desteklemektedir. Kayan'ın (2019) 40-69 yaş aralığındaki kadınların meme kanseri bilgi düzeyleri ile meme kanseri korkuları arasındaki ilişkisinin araştırıldığı çalışmasında; meme kanserinin erken evre tarama yöntemlerinden olan kendi kendine meme 
muayenesini duyma oranı \%36.4 yapma oranı ise \%17.4 olarak belirlenmiştir. Katılımcıların kendi kendine meme muayenesi yapmama nedenleri sorgulandığında \%82.6'sı bilmediğini ifade etmiştir.

Klinik meme muayenesine yönelik kadınların bilgi ve uygulama durumları sorulmuş ve kadınların \%51.5'inin duymadığı, \%13.5'inin klinik meme muayenesi yaptırdığı sonucuna ulaşmıştır. Yine aynı çalışmada, kadınların \%89.5'i mamografiyi duyduğunu, \%42.7'si de yaptırdığını belirtmiştir. Bir başka çalışmada ise; yaş ortalaması 20.20 olan kadın lisans öğrencilerinin yalnızca \%34.6'ının KKMM yapmayı bildiğini ve \%14.1'inin düzenli olarak KKMM yaptığı sonucuna ulaşılmıştır (Türkmen, 2017). Bununla birlikte meme kanseri korkusu ile ilgili yapılan çalışmalarda meme kanseri korkusunun kadınların erken tanı davranışlarını hem olumlu hem de olumsuz yönde etkilediği bildirilmiştir (Kim \& Kim, 2008; Miller, O'Hea, Lerner, Moon \& Foran-Tuller, 2011). Champion ve arkadaşları (2004) orta seviyede meme kanseri korkusu olan kadınların erken tanı davranışlarını uygulama oranlarının daha yüksek olduğunu, düşük veya yüksek düzeyde meme kanseri korkusu yaşayan kadınlarda erken tanı davranışlarını uygulama durumlarının daha düşük olduğu belirtmişlerdir. Çalışma sonuçları göz önüne alındığında erken tanıda bireylerin kendisine büyük sorumluluklar düştüğünü söylemek mümkündür. Bu anlamda kadınların yapacağı ilk uygulamanın başında kendi kendine meme muayenesi gelmektedir.

Kendi kendine meme muayenesi kadınların erken evrede meme kanserinin tanılanmasına yönelik kendi memelerini düzenli olarak incelemelerini içerir (Oladimeji ve ark., 2015; Birhane ve ark., 2017). Kendi kendine meme muayenesi ile kadınların memelerinin hem görüntüsünü hem de meme dokusunu tanımaları amaçlanmaktadır. Böylelikle kadınların memedeki anormal değişiklikleri kolayca tespit edebilmesi sağlanmaktadır (Nde ve ark., 2015; Birhane ve ark., 2017; Gençtürk, Demirezen \& Ay, 2017). Kendi kendine meme muayenesin kolay uygulanabilmesi, kadının kendisi tarafından yapılabilmesi, hızlı ve güvenli olması ve spesifik bir ekipman gerektirmemesi gibi avantajları vardır. Ancak bu avantajlara rağmen yapılan çalışmalarda çoğu kadın tarafından KKMM'nin yapılmadığı bildirilmiştir (Abolfotouh ve ark., 2015; Nde ve ark., 2015; Birhane ve ark., 2017). Kadınların KKMM yapmama nedenleri göz önüne alındığında sağlık profesyonellerine büyük görev düşmektedir. Çünkü yapılan çalışmalarda kadınların KKMM yapmama nedenlerinin en başında nasıl yapıldığı bilmemeleri gelmektedir (Mavi Aydoğdu \& Karapelit, 2017; Bayram Değer, Çiftçi, Saka \& Ceylan 2018; Kayan, 2019). Kadınların KKKM'ni yapmayı öğrenmesi ve bu konuda farkındalık kazanmaları son derece önemlidir. Bu konuda kilit noktalardan birinde de ebeler bulunmaktadır.

Ebelerin meme kanserinin erken teşhisinde önemli olan KKMM'yi kadınlara öğretmesi, meme kanserine yönelik bilgi düzeylerini artırması bu konuda farkındalık kazandırması son derece önemlidir. Bu nedenle ebelerin, meme kanserinde ve erken tanıda önemli rol oynayan KKMM'yi eğitim süreçleri boyunca öğrenmeleri ve bir kadın olarak kendilerinin de uygulaması gerekmektedir (Gençtürk, Demirezen \& Ay, 2017). Bununla birlikte çevrelerindeki kadınlara öğretmeleri de sorumluluklarından biridir.

$\mathrm{Bu}$ araştırmada ebelik bölümü öğrencilerinin ve annelerinin KKMM yapma durumları ve meme kanseri korkusu arasındaki ilişkinin belirlenmesi ve ebelik bölümü öğrencilerinin KKMM'yi etrafındaki kadınlara öğretme durumlarını belirlemek amaçlanmıştır. Bu amaç doğrultusunda aşağıdaki sorulara cevap aranmıştır:

1. Ebelik öğrencilerinin meme kanseri korkusu ne düzeydedir?

2. Annelerinin meme kanseri korkusu ne düzeydedir?

3. Düzenli olarak KKMM yapan ebelik öğrencilerinin meme kanseri korkusu ne düzeydedir?

4. Düzenli olarak KKMM yapan annelerinin meme kanseri korkusu ne düzeydedir?

5. Ebelik öğrencilerinin annelerinin ne kadarı KKMM yapmaktadır?

\section{Yöntem}

\section{Araştırmanın tipi}

Bu çalışma, tanımlayıcı ve ilişki arayıcı tipte gerçekleştirilmiştir. Örneklem

Çalışmanın evrenini, Türkiye'de, Orta Karadeniz bölgesinde bir Sağlık Bilimleri Fakültesinin Ebelik bölümünde okuyan, Kadın Sağlığı ve Hastalıkları dersini alan 3. ve 4. sınıf ebelik öğrencileri ve öğrencilerin anneleri $(N=300)$ oluşturmuştur. Araştırmanın örneklemi için evreni bilinen örneklem hesabına gidilmiş ve \%90 güven aralığı ve \pm 5 yanılma payı ile 164 kişi oluşturmaktadır. Araştırma gönüllü olarak katılmayı kabul eden 93 öğrenci ile 93 anne olmak üzere 186 kişi ile tamamlanmıştır.

\section{Verilerin toplanması}

Covid-19 pandemisi nedeniyle, verilerin toplanması için katılımcılara Google forms üzerinden hazırlanan çevrimiçi anketler iletilmiştir. Öğrenciler ve anneleri çevrimiçi anketler aracılığıyla çalışmanın amacı hakkında bilgilendirilmiş ve çalışmaya katılmayı gönüllü olarak kabul ettikten sonra veri toplama araçlarını doldurmuşlardır. Veriler 01 Mayıs-01 Haziran 2021 tarih aralığında toplanmıştır. Katılımcıların formları doldurma işlemi yaklaşık olarak 10-15 dakika sürmüştür.

\section{Veri Toplama Araçları}

Araştırmada veri toplama aracı olarak; ebelik bölümü öğrencilerinin tanımlayıcı özelliklerini ve KKKM'ye yönelik bilgi ve uygulama düzeylerini belirlemek için Kişisel Bilgi Formu 1, annelerinin tanımlayıcı özelliklerini ve KKKM'ye yönelik bilgi ve uygulama düzeylerini belirlemek için Kişisel Bilgi Formu 2 ve meme kanseri korkularını belirlemeye yönelik Meme Kanseri Korkusu Ölçeği kullanılmıştır.

\section{Kişisel Bilgi Formu 1}

Araştırmacılar tarafından öğrencilerin sosyodemografik özelliklerini belirlemeye yönelik 13 soru ve KKMM'ye yönelik bilgi ve uygulama düzeylerini belirlemek için 11 soru literatür doğrultusunda oluşturulmuştur (Secginli, 2012; Birhane ve ark., 2017; Nacar, 2018; Bakır \& Demir, 2020).

\section{Kişisel Bilgi Formu 2}

Araştırmacılar tarafından öğrencilerin annelerinin sosyodemografik özelliklerini belirlemeye yönelik 11 soru ve KKMM'ye yönelik bilgi ve uygulama düzeylerini belirlemek için 14 literatür doğrultusunda oluşturulmuştur (Secginli, 2012; Birhane ve ark., 2017; Nacar, 2018; Bakır \& Demir, 2020).

\section{Meme Kanseri Korkusu Ölçeği}

Champion ve ark. (2004) tarafından geliştirilen ölçek 8 maddelik, tek boyutlu ve beşli likert tipte bir ölçme aracıdır. Ölçme aracı Türk kültürüne Seçginli (2012) tarafından uyarlanmıştır. Ölçekteki maddeler katılımcılar tarafından "kesinlikle katılmıyorum" 1 puan, "katılmıyorum" 2 puan, "kararsızım" 3 puan, "katılıyorum" 4 puan, "tamamen katılıyorum" 5 puan şeklinde puanlanmaktadır. Ölçekten en 
düşük 8, en yüksek 40 puan alınabilmektedir. Ölçekten alınan puanlar arttıkça meme kanseri korku düzeyi artmaktadır. Ölçekten alınan 8-15 puan "düşük düzeyde korkuyu", 16-23 puan "orta derecede korkuyu", 24-40 puan ise "yüksek düzeyde korkuyu" ifade etmektedir. Orijinal ölçeğin güvenirlik katsayısı Afrikalı-Amerikan ve beyaz kadınlar için 0.91, AfroAmerikan kadınlar için 0.94 (Champion ve ark., 2004; 2008) bulunmuştur. Ölçeğin Türkçe formunun güvenirlik katsayısı 0.90 bulunmuştur (Seçginli, 2012). Bu çalışmada ise ölçeğin geneli için 0.92, annelerde cronbach alpha katsayısı 0.91, öğrencilerde ise 0,92 olarak hesaplanmıştır.

\section{Verilerin analizi}

Araştırmadan elde edilen veriler SPSS (Statistical Package for Social Sciences) 22,0 paket programında değerlendirmiştir. Verilerin değerlendirilmesinde tanımlayıcı analizler (sayı, yüzde, ortalama, standart sapma, minimum, maksimum) yapıımıştır. Veriler normal dağılıma uygunluk gösterdiğinde bağımsız gruplarda $t$ testi ve One Way ANOVA, normal dağılıma uygunluk göstermediğinde Kruskal Wallis-H testi ile analizler yapıımıştır. Çalışmada $\mathrm{p}<0.05$ anlamlılık sınırı olarak kabul edilmiştir.

\section{Araştırmanın etik yönü}

Araştırmaya başlanmadan önce Tokat Gaziosmanpaşa Üniversitesi Sosyal ve Beşeri Bilimler Araştırma Etik Kurulu'ndan 29.04.2021 tarihli, 29.04.2021/10-17 numaralı karar ile etik onay alınmıştır. Araştırmanın yürütüldüğü ilgili fakülteden uygulama izni alınmıştır. Araştırmada Meme Kanseri Korkusu Ölçeği'nin Türkçe formunu kullanmak için eposta yoluyla izin alınmıştır. Öğrenciler ve anneleri veri toplama öncesinden araştırma hakkında bilgilendirilmiş ve araştırma formu üzerinden çalışmaya katılmayı gönüllü olarak kabul ettiklerine dair seçeneği işaretlemelerinin ardından çalışmaya katılmışlardır. Araştırma Helsinki Deklerasyonu Prensipleri'ne uygun olarak yürütülmüştür.

\section{Bulgular}

Çalışmaya anketleri dolduran anne ve öğrencilerden toplam 186 katıımcı dahil edildi. Öğrencilerin yaş ortalaması 21.80 \pm 1.09 ( $\min =19, \max =26$ ) yıldır, \%66.7'si Anadolu lisesi mezunudur. Öğrencilerin \%54.8'i ebelik bölümü 3. sınıfta, \%45.2'si ise ebelik bölümü 4. sınıfta öğrenim görmektedir. Öğrencilerin \%82.8'i çekirdek aileye sahiptir, \%28.0 ilçede yaşamakta ve \%99.8'i bekardır. Öğrencilerin \%75.3'ü gelirinin giderlerine denk olduğunu bildirmiştir. Öğrencilerin \%28'inin kız kardeşi yokken, \%28.8'inin 3 ve üzeri kız kardeşi vardır. Çalışmaya katılan annelerin yaş ortalaması $48.59 \pm 5.690$ ( $\min =38$, max=65) yıldır, \%60.2'si ilkokul mezunu, \%91.4'ü evli

Tablo 1. Kendi kendine meme muayenesine yönelik bazı değişkenler

\begin{tabular}{|c|c|c|c|c|}
\hline \multirow{2}{*}{ Özellikler } & \multicolumn{2}{|c|}{ Anne } & \multicolumn{2}{|c|}{ Öğrenci } \\
\hline & $\mathbf{n}$ & $\%$ & $\mathbf{n}$ & $\%$ \\
\hline \multicolumn{5}{|l|}{ Kendisinde meme kanseri öyküsü durumu } \\
\hline Var & 1 & 1.1 & 0 & 0 \\
\hline Yok & 92 & 98.9 & & 100.0 \\
\hline \multicolumn{5}{|l|}{ Ailede meme kanseri öyküsü } \\
\hline Var & 11 & 11.8 & 11 & 11.8 \\
\hline Yok & 82 & 88.2 & 82 & 88.2 \\
\hline \multicolumn{5}{|l|}{ KKMM eğitimi alma durumu } \\
\hline Eğitim aldım & 74 & 79.6 & 92 & 98.9 \\
\hline Eğitim almadım & 19 & 20.4 & 1 & 1.1 \\
\hline \multicolumn{5}{|l|}{ KKMM eğitimi aldığı yer } \\
\hline Okul & & & 93 & 100.0 \\
\hline Sağlık Personeli & 15 & 16.1 & & \\
\hline Ebelik Öğrencisi Kızımdan & 22 & 23.7 & & \\
\hline Diğer & 18 & 19.4 & & \\
\hline Sağlık Personeli-Kızım & 12 & 12.9 & & \\
\hline Sağlık Personeli-Diğer & 9 & 9.7 & & \\
\hline Diğer-Kızım & 2 & 2.2 & & \\
\hline Hepsi & 1 & 1.1 & & \\
\hline \multicolumn{5}{|l|}{ KKMM yapma durumu } \\
\hline Yapıyor & 60 & 64.5 & 79 & 84.9 \\
\hline Yapmıyor & 33 & 35.5 & 14 & 15.1 \\
\hline Toplam & 93 & 100 & 93 & 100 \\
\hline \multicolumn{5}{|l|}{${ }^{\star} \mathrm{KKMM}$ yapma süresi } \\
\hline 1 yıl ve daha az & 4 & 6.7 & 15 & 19,0 \\
\hline 1 ila 5 yıl arası (5 dahil) & 38 & 63.3 & 59 & 74.7 \\
\hline 5 yıl ile 10 yıl arası & 7 & 11.7 & 5 & 6.3 \\
\hline 10 yıl ve üzeri & 11 & 18.3 & - & - \\
\hline \multicolumn{5}{|l|}{ *KKMM yapma sıklığı } \\
\hline Her banyodan sonra & 11 & 18.3 & 15 & 19.0 \\
\hline Ayda bir kez & 22 & 36.7 & 41 & 51.9 \\
\hline İki üç ayda bir kez & 24 & 40.0 & 20 & 25.3 \\
\hline Yılda bir kez & 3 & 5.0 & 3 & 3.8 \\
\hline \multicolumn{5}{|l|}{ *KKMM yapma zamanı } \\
\hline Her banyoda & 14 & 23.3 & 11 & 13.9 \\
\hline Menstrual siklus sürecinde & 6 & 10.0 & 20 & 25.3 \\
\hline Menstrual siklus bitiminden 5-7 gün sonra & 12 & 20.0 & 35 & 44.3 \\
\hline Herhangi bir zamanda & 28 & 46.7 & 13 & 16.5 \\
\hline Toplam & 60 & 100 & 79 & 100 \\
\hline
\end{tabular}


Tablo 2. Kendi kendine meme muayenesi yapma yöntemlerine ilişkin bazı değişkenler

\begin{tabular}{|c|c|c|c|c|}
\hline & \multicolumn{2}{|c|}{ Anne } & \multicolumn{2}{|c|}{ Öğrenci } \\
\hline & $\mathbf{n}$ & $\%$ & $\mathbf{n}$ & $\%$ \\
\hline \multicolumn{5}{|l|}{ Meme muayenesinin yapılma pozisyonu } \\
\hline \multicolumn{5}{|l|}{ Ayna karşısında gözle } \\
\hline Evet & 26 & 43.3 & 44 & 55.7 \\
\hline Hayır & 34 & 56.7 & 35 & 44.3 \\
\hline \multicolumn{5}{|l|}{ Ayna karşısında elle } \\
\hline Evet & 34 & 56.7 & 56 & 70.9 \\
\hline Hayır & 26 & 43.3 & 23 & 29.1 \\
\hline \multicolumn{5}{|l|}{ Sırtüstü pozisyonda yatarak } \\
\hline Evet & 18 & 30.0 & 29 & 36.7 \\
\hline Hayır & 42 & 70.0 & 50 & 63.3 \\
\hline \multicolumn{5}{|l|}{ Banyo sırasında } \\
\hline Evet & 30 & 50.0 & 45 & 57.0 \\
\hline Hayır & 30 & 50.0 & 34 & 43.0 \\
\hline \multicolumn{5}{|l|}{ Muayene sırasında değerlendirilen bölge } \\
\hline \multicolumn{5}{|l|}{ Meme dokusu } \\
\hline Evet & 58 & 96.7 & 73 & 92.4 \\
\hline Hayır & 2 & 3.3 & 6 & 7.6 \\
\hline \multicolumn{5}{|l|}{ Meme ucu } \\
\hline Evet & 41 & 68.3 & 60 & 75.9 \\
\hline Hayır & 19 & 31.7 & 19 & 24.1 \\
\hline \multicolumn{5}{|l|}{ Koltukaltı } \\
\hline Evet & 45 & 75.0 & 68 & 86.1 \\
\hline Hayır & 15 & 25.0 & 11 & 13.9 \\
\hline \multicolumn{5}{|l|}{ Meme ucunu sıkarak } \\
\hline Evet & 22 & 36.7 & 36 & 45.6 \\
\hline Hayır & 38 & 63.3 & 43 & 54.4 \\
\hline \multicolumn{5}{|l|}{ Meme muayenesi yapılma yöntemi } \\
\hline -Meme başı çevresinden başlayarak dairesel hareketlerle bütün meme dokusunu parmak uçlarımla tararım & 17 & 28.3 & 20 & 25.3 \\
\hline -Meme dış sınırından başlayarak dairesel hareketlerle meme ucuna doğru parmak uçlarımla tararım & 15 & 25.0 & 30 & 38.0 \\
\hline -Memenin üst dış sınıından başlayarak çizgisel hareketlerle memenin sağına ve soluna doğru parmak uçlarımla tararım & 13 & 21.7 & 13 & 16.5 \\
\hline $\begin{array}{l}\text {-Memenin dışından ok hareketleri memenin ucunda sonlanan oklar şeklinde çizgisel hareketlerle parmak uçlarımla } \\
\text { tararım }\end{array}$ & 15 & 25.0 & 16 & 20.3 \\
\hline Toplam & 60 & 100 & 79 & 100 \\
\hline
\end{tabular}

\%90.3'ü gelir getiren bir işte çalışmamaktadır. Annelerden \%82.8'i çekirdek aile tipine sahip olduğunu bildirmiştir. Annelerin \%30.1'i ilçede yaşamakta ve \%73.1'inin gelirinin giderlerine denk olduğu belirlenmiştir. Çalışmaya katılan öğrencilerin (\%11.8'i) ve annelerin (\%11.8) az bir kısmı ailede meme kanseri öyküsü olduğunu bildirmiştir. Annelerin \%1.1'i ise kendisinde meme kanseri öyküsü olduğunu bildirmiştir. Annelerin \%79.6'sı KKMM ye yönelik eğitim aldığını, KKMM ye yönelik eğitimi \%23.7'si ebelik bölümünde okuyan kızından aldığını belirtmiştir. Araştırmaya katılan annelerin \%64.5’i KKMM yaptığını bildirmiştir. Meme muayenesi yaptığını bildiren annelerin \%63.3'ü 1 ila 5 yıldır meme muayenesi yaptığını bildirmiştir. Annelere meme muayenesini ne sıklıkta yaptığı sorgulandığında \%40'ı 2-3 ayda bir kez meme muayenesi yaptığını belirtmiştir. Meme muayenesi yapma zamanı sorgulandığında \%46.7'si ise herhangi bir zamanda muayene yaptığını bildirmiştir. Öğrencilerin \%98.9'u KKMM'ye yönelik eğitim aldığını ve \%100'ü bu eğitimi okuldan aldıklarını bildirmiştir. Kendi kendine meme muayenesini öğrencilerin \%84.9'u yapmaktadır ve bu öğrencilerin \%74.7'si 1 ila 5 yıldır yaptığını belirtmiştir. Meme muayenesi ne sıklıkta yaptığı sorgulandığında öğrencilerin \%51.9'u ayda bir kez yaptığını belirtmiştir. Katılımcı öğrencilere Meme muayenesi yapma zamanı sorgulandığında \%44.3'ü adetinin bitiminden 5-7 gün sonra muayene yaptığını bildirmiştir (Tablo 1).

Katılımcılara kendi kendine meme muayenesini hangi yöntemlerle yaptıkları sorulduğunda annelerin \%43.3'ü ayna karşısında gözle değerlendirdiğini, \%56.7'si ayna karşısında elle muayene ettiğini, \%30'u sırtüstü yatarak, \%50'si ise banyoda değerlendirdiğini belirtmiştir. Öğrencilerin \%55.7'si ayna karşısında gözle değerlendirdiğini, \%70.9'u ayna karşısında elle muayene ettiğini, \%36.7'u sırtüstü yatarak, \%57.0'si ise banyoda değerlendirdiğini belirtmiştir. Annelerin \%96.7' si meme dokusunu değerlendirdiğini, \%68.3 'ü meme ucunu değerlendirdiğini, \%75.0'ı koltuk altını değerlendirdiğini, \%36.7'si meme ucunu sıkarak değerlendirme yaptığını belirtmiştir. Ayrıca annelerin \%28.3'ü meme muayenesini meme başı çevresinden başlayarak dairesel hareketlerle bütün meme dokusunu parmak uçlarıyla taradığı belirlenmiştir. Öğrencilerin \%92.4'ü meme dokusunu değerlendirdiğini, \%75.9'u meme ucunu değerlendirdiğini, \%86.1'i koltuk altını değerlendirdiğini, \%45.6'sı meme ucunu sıkarak değerlendirme yaptığını belirtmiştir. Ayrıca öğrencilerin \%25.3'ü meme muayenesini meme başı çevresinden başlayarak dairesel hareketlerle bütün meme dokusunu parmak uçlarıyla taradığı belirlenmiştir (Tablo 2). Annelerin \%50.5' i doktor tarafından meme muayenesi olduğunu, meme muayenesi olduğunu bildiren annelerin \%46.8'i 1-3 yılda bir muayene olduğunu bildirmiştir. 40 yaş ve üzerinde olan 88 annenin \%53.4'ü mamografi çektirdiğini, mamografi çektirme sıklığını \%34.2'si 2 yıl ve daha uzun sürede olduğunu bildirmişlerdir (Tablo 3). Öğrencilerin kendi kendine meme muayenesi eğitimi aldıktan sonra kendi kendine meme muayenesini \%50.5'si kız kardeşlerine, \%71'i ise annelerine öğrettiklerini bildirmişlerdir. Çalışmada katılımcıların Meme Kanseri Korkusu Ölçeği'nden aldığı ortalama puan $25.38 \pm 7.376(\min =8$, $\max =40)$, annelerin 
Tablo 3. Annelerin klinik meme muayenesi yaptırma ve mamografi çektirme durumları

\begin{tabular}{|c|c|c|}
\hline & \multicolumn{2}{|c|}{ Anne } \\
\hline & $\mathbf{n}$ & $\%$ \\
\hline \multicolumn{3}{|c|}{ Doktora meme muayenesi yaptırma durumu } \\
\hline Evet & 47 & 50.5 \\
\hline Hayır & 46 & 49.5 \\
\hline \multicolumn{3}{|c|}{ Doktora meme muayenesi için gitme sıklığı } \\
\hline Hiç yaptırmadım & 46 & 49.5 \\
\hline Yılda bir kez yaptırırım & 7 & 7.5 \\
\hline $1-3$ yılda bir yaptırırım & 22 & 23.7 \\
\hline 4 yıldan daha fazla sürede yaptırırım & 18 & 19.4 \\
\hline Toplam & 93 & 100 \\
\hline \multicolumn{3}{|c|}{ Mamografi çektirme durumu (40 yaş ve üzerinde iseniz cevaplayınız) } \\
\hline Evet & 47 & 53.4 \\
\hline Hayır & 41 & 46.6 \\
\hline \multicolumn{3}{|c|}{ Mamografi çektirme sıklığı (40 yaş ve üzerinde iseniz cevaplayınız) } \\
\hline 2 yılda bir & 16 & 18.2 \\
\hline 2 yıldan daha fazla sürede & 31 & 35.2 \\
\hline Hiç yaptırmadım & 41 & 46.6 \\
\hline Toplam & 88 & 100 \\
\hline
\end{tabular}

ölçekten aldığı ortalama puan $25.75 \pm 7.28$ ( $\min =8, \max =40$ ), öğrencilerin ölçekten aldığı ortalama puan $25.00 \pm 7.491$ $(\min =8, \max =40)$ 'dır. Annelerin ve öğrencilerin ölçekten aldıkları puan değerlendirildiğinde yüksek derecede meme kanseri korkusuna sahip oldukları belirlenmiştir. Araştırma kapsamında katılımcıların bazı özellikleri ile ölçekten alınan puanlar arasında ilişki aranmıştır. Annelerin yaşadığı yer, aile tipi, gelir durumu, ailede meme kanseri öyküsü, KKMM eğitim alma durumu, KKMM eğitimi alınan kişi, KKMM yapma durumu, yapma süresi, yapma sıklığı, eğitim düzeyi, gelir getiren bir işte çalışma durumu, doktora meme muayenesi yaptırma durumu, doktora meme muayenesi yaptırma sıklığı, mamografi çektirme durumu ile ölçekten alınan puanlar arasında anlamlı bir ilişki saptanmamıştır $(p<0.05)$. Öğrencilerin yaşadığı yer, aile tipi, gelir durumu, ailede meme kanseri öyküsü, KKMM eğitim alma durumu, KKMM eğitimi alınan kişi, KKMM yapma durumu, yapma süresi, yapma sıklığı, mezun olduğu lise, gelir getiren bir işte çalışma durumu ve KKMM'yi kız kardeşlerine ve annelerine öğretme durumu ile ölçekten alınan puanlar arasında anlamlı bir ilişki saptanmamıştır $(p<0.05)$ (Tablo 4).

Annelerin kendi kendine meme muayenesi yapma zamanı ile ölçekten alınan puanlar arasında anlamlı bir farklılık bulunmazken $(p<0.05)$, öğrencilerin kendi kendine meme muayenesi yapma zamanı ile ölçekten alınan puan arasında anlamlı bir ilişki bulunmuştur $(p<0.05)$. Yapılan post-hoc analizinde ebelik öğrencilerinde her banyo sonrası KKMM yapan grubun herhangi bir zamanda meme muayenesi yapan gruba göre meme kanseri korkusu ölçeğinden aldığı puan yüksek olarak bulunmuştur (Tablo 4).

\section{Tartışma}

Meme kanserinin erken tanılanmasıyla, meme kanserinin tedavi şansı artabilir ve yaşam süresi uzayabilir. Bu nedenle erken tanı davranışlarının kazanılması son derece önemlidir (Karayurt, Coşkun \& Cerit, 2008). Erken tanı davranışlarından biri olan KKMM'nin yapılması primer olarak kadının kendi sorumluluğundadır. Ancak kadınların bu konuya yönelik eğitim almaları, muayeneyi doğru yapabilmelerini sağlamak adına gereklidir.

Çalışmamızda annelerin \%79.6'sı, öğrencilerin ise tamamı KKMM eğitimini aldığını bildirmişlerdir. Ebelik bölümü öğrencileri ile yapılan bir çalışmada \%76.34'ü KKMM hakkında bilgi aldığını bildirmiştir (Mavi Aydoğdu \& Karapelit, 2017).
Çidem ve Ersin'in (2019) çalışmasında ise kadınların \%57.6'sı daha önce meme kanseri ve erken tanı yöntemleri hakkında bilgi aldığı tespit edilmiştir. Faklı bir çalışmada kadınların \%19'unun KKMM hakkında bilgi aldığı bulunmuştur (Kartal, İnci, Koştu \& Çınar, 2017). Araştırmamızda katılımcıların KKMM eğitimi alma durumlarının benzer sonuçlar gösterdiğini söylemek mümkündür. Araştırmamızda anneler KKKM'ye yönelik bilgiyi \%23.7'si ebelik öğrencisi kızından, \%19.4'ü diğer kaynaklardan (internet, televizyon, kitap, dergi ve broşürden) aldığını bildirmişlerdir. Çidem ve Ersin (2019) araştırmalarında KKMM yönelik bilgiyi kadınların \%52.7'sinin televizyon/radyodan edindiklerini bulmuşlarıdır. Literatürde bu konuda bilgi edinme konusunda farklı yaklaşımların olduğunu söylemek mümkündür.

Araştırmamızda öğrencilerin tamamı KKKM'ye yönelik bilgiyi okuldan aldığını bildirmiştir. Tıp fakültesi öğrencileri ile yapılan bir çalışmada öğrencilerin \%39.2'sinin KKMM ye yönelik bilgiyi derslerden edindiği (Yılmaz, Emre \& Aykota, 2020), bir başka çalışmada ise Üniversite öğrencilerinin KKMM hakkındaki bilgiyi en çok sağlık personelinden (\%55.6) aldıkları belirtilmiştir (Bayram Değer ve ark., 2018). Araştırmamızda öğrencilerin diğer çalışmalarla benzer şekilde bilgi edinme yollarının okul ya da ders müfredatının bir parçası olarak bu konuda bilgi aldıklarını söylemek mümkündür.

Nacar'ın (2018) çalışmasında, kadınların \%39.7'sinin KKMM yaptığı bulunmuştur. Bir başka çalışmada ise katılımcıların \%42.9'unun kendi kendine meme muayenesi yaptığı bildirilmiştir (Yılmaz, Emre \& Aykota, 2020). Araştırmamızda annelerin \%64.5'i KKMM yaptığını bildirmiştir. Ebelik bölümü öğrencileri ile yapılan bir çalışmada, öğrencilerin \%48.42'sinin KKMM yaptığı tespit edilmiştir (Mavi Aydoğdu \& Karapelit, 2017). Araştırmamızda ebelik öğrencilerinin \%84.9'u KKMM yaptığını ifade etmiştir. Araştırmamızın sonuçlarının diğer çalışmalarla benzer olduğunu söylemek mümkündür.

Araştırmamızda meme muayenesi yapan annelerin \%46.7'si herhangi bir zamanda KKMM yaparken, Kartal ve arkadaşlarının (2017) çalışmasında kadınların \%88.9'unun aklına geldikçe KKMM yaptığı belirlenmiştir. Çalışmaya katılan öğrencilerin \%51.9'unun ayda bir kez meme muayenesi yaptığı sonucuna ulaşılmıştır. Ebelik öğrencileri ile yapılan çalışmada KKMM yapanların \%30.4'ünün her ay meme muayenesi yaptığı bildirilmiştir (Mavi Aydoğdu \& Karapelit, 2017).

Bayram Değer ve arkadaşları (2018) sağlık alanı dışında okuyan üniversite öğrencileri ile yaptığı çalışmada öğrencilerin \%66.11'i memeyi gözle muayene ettiği, \%47.22'si palpasyon yaptığı, \%52.78'inin ayakta palpasyon yaptığını, \%36.11'inin yatarak palpasyon yaptığını bulmuşlardır. Araştırmamızda meme muayenesini Öğrencilerin \%55.7'si ayna karşısında gözle değerlendirdiğini, \%70.9'u ayna karşısında elle muayene ettiğini, \%36.7'u sırtüstü yatarak, \%57'si ise banyoda 
Tablo 4. Katılımcıların bazı özellikleri ile meme kanseri korkusu ölçeğinden alınan puanlar arasındaki ilişki

\begin{tabular}{|c|c|c|c|c|c|c|}
\hline \multirow{2}{*}{ Özellikler } & \multicolumn{3}{|c|}{ Anne } & \multicolumn{3}{|c|}{ Öğrenci } \\
\hline & $\mathbf{n}$ & 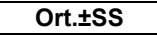 & Test ve $p$ & $\mathbf{n}$ & 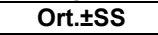 & Test ve $p$ \\
\hline Yaşanılan yer & & & & & & \\
\hline Köy & 17 & $24.82 \pm 8.00$ & & 19 & $24.89 \pm 7.36$ & \\
\hline İlçe & 28 & $26.50 \pm 7.64$ & $\mathrm{~F}=0.608$ & 26 & $24.73 \pm 8.30$ & $F=0.196$ \\
\hline Büyükşehir & 29 & $24.69 \pm 7.47$ & & 29 & $25.83 \pm 7.31$ & \\
\hline Aile Tipi & & & & & & \\
\hline Çekirdek aile & 77 & $25.68 \pm 7.08$ & & 77 & $24.68 \pm 7.38$ & \\
\hline Geniş aile & 10 & $29.20 \pm 7.31$ & $F=2.192$ & 9 & $28.56 \pm 6.74$ & $F=0.763$ \\
\hline Parçalanmış aile & 3 & $17.33 \pm 9.71$ & $\mathrm{p}=0.94$ & 4 & $23.75 \pm 10.93$ & $p=0.518$ \\
\hline Ebeveynlerden birinin vefat ettiği aile & 3 & $24.67 \pm 5.03$ & & 3 & $24.33 \pm 9.07$ & \\
\hline Gelir durumu & & & & & & \\
\hline Gelir giderden az & 16 & $26.13 \pm 7.71$ & $F=0.256$ & 13 & $25.08 \pm 8.41$ & $F=0.576$ \\
\hline Gelir gidere denk & 68 & $25.88 \pm 7.01$ & $\mathrm{p}=0.774$ & 70 & $25.33 \pm 7.06$ & $\mathrm{p}=0.564$ \\
\hline Gelir giderden fazla & 9 & $24.11 \pm 9.07$ & & 10 & $22.60 \pm 9.44$ & \\
\hline Ailede meme kanseri öyküsü & & & & & & \\
\hline Evet & 11 & $26.64 \pm 7.27$ & $\mathrm{t}=0.427$ & 11 & $23.91 \pm 7.32$ & $\mathrm{t}=0.512$ \\
\hline Hayır & 82 & $25.63 \pm 7.31$ & $\mathrm{p}=0.670$ & 82 & $25.15 \pm 7.54$ & $\mathrm{p}=0.61$ \\
\hline Kendi kendine meme muayenesine & la du & & & & & \\
\hline Evet & 74 & $25.35 \pm 7.68$ & $t=1.050$ & 92 & $25.17 \pm 7.34$ & $\mathrm{t}=2.192$ \\
\hline Kendi kendine meme muayenesine & $\tan \mathrm{k}$ & & & & & \\
\hline Sağlık personeli & 15 & $25.07 \pm 7.53$ & & & & \\
\hline Ebelik öğrencisi kızım & 22 & $26.36 \pm 8.93$ & & & & \\
\hline Diğer (arkadaş, akraba...) & 18 & $25.39 \pm 7.64$ & $\mathrm{~F}=0.142$ & & & \\
\hline Hepsi & 2 & $23.50 \pm 0.707$ & $\mathrm{p}=0.990$ & & & \\
\hline Sağlık personeli- kızım & 12 & $24.50 \pm 7.62$ & & & & \\
\hline Diğer-kızım & 9 & $25.33 \pm 4.61$ & & & & \\
\hline Sağlık personeli-diğer & 1 & - & & & & \\
\hline Okul & - & - & & 93 & $25.0 \pm 7.49$ & \\
\hline Kendi kendine meme muayenesi ya & & & & & & \\
\hline Yapıyor & 60 & $25.17 \pm 7.01$ & $\mathrm{t}=1.047$ & 79 & $24.80 \pm 7.21$ & $t=0.617$ \\
\hline Yapmıyor & 33 & $26.82 \pm 7.72$ & $p=0.298$ & 14 & $26.14 \pm 9.13$ & $\mathrm{p}=0.539$ \\
\hline Toplam & & & & & & \\
\hline Meme muayenesi yapma süresi* & & & & & & \\
\hline 1 yıl ve daha az & 4 & $26.75 \pm 4.71$ & & 15 & $27.40 \pm 5.66$ & \\
\hline 1 ve 5 yıl arası & 38 & $24.47 \pm 6.55$ & $F=0.218$ & 59 & $23.92 \pm 7.53$ & $\mathrm{~F}=1.779$ \\
\hline 5 ve 10 yıl arası & 7 & $24.57 \pm 9.37$ & $\mathrm{p}=0.884$ & 5 & $27.40 \pm 5.81$ & $p=0.176$ \\
\hline 10 yıl ve üzeri & 11 & $23.91 \pm 8.28$ & & - & - & \\
\hline Meme muayyeni yapma sıklığı* & & & & & & \\
\hline Her banyodan sonra & 11 & $27.82 \pm 8.76$ & & 15 & $25.00 \pm 7.88$ & \\
\hline Kendi kendine meme muayenesi ya & & & & & & \\
\hline Her banyoda & 15 & $25.87 \pm 8.40$ & & 11 & $28.27 \pm 7.226$ & \\
\hline Adet başlangıcından 5-7 gün sonra & 6 & $21.67 \pm 3.67$ & $F=0.678$ & 20 & $24.30 \pm 6.98$ & $F=2.770$ \\
\hline Adet bitiminden $5-7$ gün sonra & 12 & $24.50 \pm 7.05$ & $p=0.569$ & 36 & $25.69 \pm 5.98$ & $\mathrm{p}=0.047$ \\
\hline Herhangi bir gün & 29 & $25.86 \pm 6.69$ & & 13 & $20.54 \pm 9.01$ & \\
\hline Eğitim düzeyi & & & & & & \\
\hline Okur-yazar & 8 & $27.75 \pm 10.02$ & & & & \\
\hline İlkokul & 56 & $26.02 \pm 7.19$ & $\mathrm{~K}=6.326$ & & & \\
\hline Ortaokul & 9 & $25.67 \pm 4.69$ & $p=0.276$ & & & \\
\hline Lise & 12 & $23.75 \pm 6.69$ & & & & \\
\hline Lisans-Önlisans & 7 & $22.86 \pm 7.22$ & & & & \\
\hline Lisanüstü & 1 & - & & & & \\
\hline Gelir getiren bir işte çalışma durum & & & & & & \\
\hline Evet & 9 & $28.22 \pm 10.04$ & $W=270.500$ & & & \\
\hline Hayır & 84 & $25.49 \pm 10.69$ & $p=0.162$ & & & \\
\hline Doktora meme muayenesi yaptırma & & & & & & \\
\hline Evet & 47 & $24.51 \pm 7.26$ & $t=1.680$ & & & \\
\hline Hayır & 46 & $27.02 \pm 7.14$ & $p=0.96$ & & & \\
\hline Doktora meme muayenesi yaptırma & & & & & & \\
\hline Hiç yaptırmadım & 46 & $27.02 \pm 7.14$ & & & & \\
\hline Yılda bir kez yaptırırım & 7 & $26.29 \pm 6.89$ & $F=1.493$ & & & \\
\hline $1-3$ yılda bir & 22 & $25.32 \pm 6.29$ & $\mathrm{p}=0.222$ & & & \\
\hline 4 yıldan daha uzun sürede & 18 & $22.83 \pm 8.49$ & & & & \\
\hline Mamografi çektirme durumu & & & & & & \\
\hline Evet & 48 & $25.02 \pm 7.39$ & $t=1.001$ & & & \\
\hline Hayır & 45 & $26.53 \pm 7.15$ & $\mathrm{p}=0.319$ & & & \\
\hline Kaç yılda bir mamografi çektirirsini & & & & & & \\
\hline 2 yilda bir & 16 & $26.50 \pm 6.98$ & $F=0.997$ & & & \\
\hline 2 yıldan daha fazla uzun sürede & 32 & $24.28 \pm 7.59$ & $\mathrm{p}=0.373$ & & & \\
\hline Hiç yaptırmadım & 45 & $26.53 \pm 7.15$ & & & & \\
\hline Mezun olunan lise türü & & & & & & \\
\hline Normal Lise & & & & 6 & $25.17 \pm 9.74$ & \\
\hline Sağlık Meslek Lisesi & & & & 17 & $22.88 \pm 8.11$ & $\mathrm{~K}=2.232$ \\
\hline Anadolu Lisesi & & & & 62 & $25.45 \pm 7.40$ & $p=0.693$ \\
\hline Fen Lisesi & & & & 1 & - & \\
\hline Diğer & & & & 7 & $26.14 \pm 5.58$ & \\
\hline Öğrencilerin KKMM'yi kız kardeşler & & & & & & \\
\hline Evet & & & & 47 & $24.85 \pm 7.32$ & $t=0.193$ \\
\hline $\begin{array}{l}\text { Hayır } \\
\text { Öğrencilerin KKMM'yi annelerine ö }\end{array}$ & & & & 46 & $25.15 \pm 7.73$ & $p=0.848$ \\
\hline
\end{tabular}

K: Kruskal Wallis Testi, W: Wilcoxon Testi, F: One Way ANOVA 
banyoda değerlendirdiğini belirtmiştir. Annelerin \%43.3'ü ayna karşısında gözle değerlendirdiğini, \%56.7'si ayna karşısında elle muayene ettiğini, \%30'u sırtüstü yatarak, \%50'si ise banyoda yaptıklarını belirtmiştir.

Araştırmamızda annelerin \%50.5' inin doktora klinik meme muayenesi yaptırdığını, bu annelerin de \%46.8'i 1-3 yılda bir klinik meme muayenesi yaptırdığını bildirmiştir. Katılımcı annelerin \%53.4'ü mamografi çektirdiğini, mamografi çektirme sıklığını \%34.2'si 2 yıl ve daha uzun sürede olduğunu bildirmişlerdir. Nacar'ın (2018) çalışmasında kadınların \%18.3'ünün klinik meme muayenesi yaptırdığı ve \%15.8'inin ise mamografi çektirdiğini saptanmıştır. Farklı bir çalışmada ise kadınların \%32.0'ı meme kanseri taraması yaptırmak için sağlık kuruluşuna başvurduğu, \%24.7'si klinik meme muayenesi yaptırdığı, \%27.5'i mamografi çektirdiği bulunmuştur (Çidem, \& Ersin, 2019). Bir başka çalışmada kadınların \%20.9'unun mamografi çektirdiklerini bulmuşlardır (Özer, Bankaoğlu, Ekerbiçer, Hüdayioğlu \& Özdemir, 2009). Araştırmamızın sonuçlarının literatürle benzer olduğunu söylemek mümkündür. Bayram Değer ve arkadaşlarının (2018) çalışmasında KKMM' yi hiç uygulamayan öğrencilerin meme muayenesini uygulamama nedenleri nasıl yapılacağını bilmeme, meşgul olma, utanma, yaşını genç olarak görme, meme kanserini düşünmeme, korkma ve önemsememe olarak bildirilmiştir. Sağlık çalışanları ile yapılan farklı bir çalışmada KKMM yapmama nedenleri, gerekli olmadığı inancı ve ihmal (\%45.8), kanser olmama düşüncesi (\%15.7) ve korku (\%13.3) olarak bildirilmiştir (Akpınar, Baykan, Naçar, Gün \& Çetinkaya, 2011). Korku faktörü ele alındığından kişiler korku mevcutsa bu durum kendi kendine meme muayenesi yapmayı engelleyebilirken bizim çalışmamızda ise muayeneyi yaptıkları görülmüştür. Özer ve arkadaşlarının (2010) çalışmasında ise katılımcıların \%1.5’i korktuğu için KKMM yapmadığını bulmuşlardır.

Annelerin ve öğrencilerin meme kanseri korkusu puanı ile bazı değişkenler arasında ilişkiye bakıldığında yalnızca öğrencilerin kendi kendine meme muayenesi yapma zamanı ile ölçekten alınan puan arasında anlamlı bir ilişki bulunmuştur. Yapılan post-hoc analizinde ebelik öğrencilerinde her banyo sonrası KKMM yapan grubun herhangi bir zamanda meme muayenesi yapan gruba göre meme kanseri korkusu ölçeğinden aldığı puan yüksek olarak bulunmuştur. Meme muayenesi yapma sıklığının fazla olması meme kanseri korkusunu etkilediği düşünülmektedir. Literatürde kız öğrencilere KKMM eğitiminin annelerinin farkındalığı üzerindeki etkisini ölçmek için 100 üniversite öğrencisi ve anneleri ile yapılan bir çalışmada Öğrencilere KKMM konusunda eğitim verildikten sonra annelerine bu konuda eğitim vermeleri istenmiştir. Çalışma sonucunda KKMM eğitiminin annenin bu konudaki bilgisini olumlu yönde etkilediği bulunmuştur (Abasi, Tahmasebi, Zafari, Tofigi \& Hassani, 2018). Sağlık çalışanları ile yapılan bir çalışmada katıımcıların \%31.1'i meme kanseri konusunda risk altında hissettiği bulunmuş. Ancak risk altında hissetmek ile KKMM yapmak arasında ilişki olmadığı, risk altında hissedenlerde klinik meme muayenesi ve mamografi çektirme oranları arasında ilişki olduğu bulunmuş (Akpınar ve ark., 2011).

\section{Sonuç ve Öneriler}

Meme kanseri tüm dünyada kadınların sağlığını etkileyen önemli bir hastalık halini almıştır. Bu hastalıkta erken tanı davranışlarının kazandırılması ile erken tespit ve tedavi sağlanabilir. Bu nedenle kendi sağlık durumlarını takip etme sorumluluğu olan kadınların KKMM'si yapmaları gerekmektedir.
Bu muayeneyi yapabilmeleri için öncelikle eğitim almaları ve bu eğitime göre meme dokusundaki değişiklikleri belirleyebilmesi sağlanabilir. Eğitim hayatlarında ebelik bölümü öğrencileri lisans eğitimi sürecinde KKMM'sine yönelik eğitimler almaktadır. Aldıkları bu eğitimi annelerine de öğrettikleri ve kendileri de meme muayenesi yaptıkları bulunmuştur. Öğrencilerin ve annelerinin meme kanseri korkusu düzeyleri yüksektir. Ancak meme kanseri korku düzeyinin KKMM'si yapma durumunu etkilemediği bulunmuştur. Bu nedenle KKMM yapma durumunu belirlemeye yönelik olarak farklı faktörlerin etkisini araştıran çalışmalara gereksinim duyulmaktadır.

\section{Çıkar Çatışması}

Çıkar çatışması bulunmamaktadır.

\section{Teşekkür}

Bu çalışmaya gönüllü olarak katılan katılımcılara teşekkür ederiz.

\section{Finansal Destek}

Bu çalışmada finansal destek alınmamıştır

\section{Etik Komite Onayı}

Araştırma için Tokat Gaziosmanpaşa Üniversitesi Sosyal ve Beşeri Bilimler Araştırma Etik Kurulu'ndan etik onay alınmıştır. (Karar No: 29.04.2021/10-17, Tarih: 29.04.2021).

\section{Bilgilendirilmiş Onam}

Çalışmaya katılanlardan onam alınmıştır.

\section{Hakem Değerlendirmesi}

Dış bağımsız.

\section{Yazar Katkıları}

A.K., M.Ş.A: Fikir, Tasarım, Analiz, Kaynak Taraması, Makalenin Yazımı, Eleştirel İnceleme

Ö.Ç: Fikir, Tasarım, Danışmanlık, Analiz, Makalenin Yazımı, Eleştirel İnceleme

\section{Kaynaklar}

Abasi, E., Tahmasebi, H., Zafari, M., Tofigi, M., \& Hassani, S. (2018). The impact of female students' breast self-examination training on their mothers' awareness. Journal of Midwifery and Reproductive Health, 6(4), 1454-1461.

Abolfotouh, M. A., Ala'a, A. B., Mahfouz, A. A., Al-Assiri, M. H., AlJuhani, A. F., \& Alaskar, A. S. (2015). Using the health belief model to predict breast self examination among Saudi women. BMC Public Health, 15(1), 1-12.

Akpınar, Y. Y., Baykan, Z., Naçar, M., Gün, İ., \& Çetinkaya, F. (2011) Knowledge, attitude about breast cancer and practice of breast cancer screening among female health care professionals: a study from Turkey. Asian Pacific Journal of Cancer Prevention, 12(11), 3063-3068.

Bakır, N., \& Demir, C. (2020) 'Hemşirelerin meme kanseri endişe düzeyi ile erken tanı uygulama davranışları arasındaki ilişki', Adıyaman Üniversitesi Sağlık Bilimleri Dergisi, 6(2), 216-222. doi:10.30569.adiyamansaglik.731912

Birhane, K., Alemayehu, M., Anawte, B., Gebremariyam, G., Daniel, R., Addis, S., ... \& Negash, W. (2017). Practices of breast selfexamination and associated factors among female debre berhan university students. International journal of Breast Cancer, 2017(1), 1-6 doi: https://doi.org/10.1155/2017/8026297

Champion, V. L., Skinner, C. S., Menon, U., Rawl, S., Giesler, R. B., Monahan, P., \& Daggy, J. (2004). A breast cancer fear scale: psychometric development. Journal of Health Psychology, 9(6), 753-762. https://doi.org/10.1177/1359105304045383 
Çidem, F., \& Ersin, F. (2019). Kadınların sosyal destek ve öz etkililik algılarının meme kanseri erken tanı davranışlarına etkisi. JERN, 16(3), 183-190.

Bayram Değer, V., Çiftçi, S., Saka, G., \& Ceylan A. (2018). Üniversite öğrencilerin kendi kendine meme muayenesi bilgi düzeyleri. Sürekli Tıp Eğitimi Dergisi, 27(5), 343-351.

Gençtürk, N., Demirezen, E., \& Ay, F. (2017). Health beliefs of midwifery students at Istanbul University about breast cancer and breast self-examination acknowledgements. Journal of Cancer Education, 32(4), 784-789. https://doi.org/10.1007/s13187-0161014-5

Karayurt, Ö., Coşkun, A., \& Cerit, K. (2008). Hemşirelerin meme kanseri ve kendi kendine meme muayenesine ilişkin inançları ve uygulama durumu. Meme Sağlığı Dergisi, 4(1), 15-20.

Kartal, A., İnci, F.H, Koştu, N., \& Çınar, İ.Ö. (2017). Effect of individual training given to women in the home environment on health beliefs for breast selfexamination. Pamukkale Medical Journal, 10(1), 713. doi: $10.5505 /$ ptd.2017.35651.

Kayan, S. (2019). Kadınların meme kanseri bilgi düzeyleri ile meme kanseri korkuları arasındaki ilişki (Yayınlanmamış Yüksek Lisans Tezi) Pamukkale Üniversitesi Sağlık Bilimleri Enstitüsü, Denizli.

Kim, J. H., \& Kim, O. (2008). Predictors of perceived barriers to mammography in korean women. Asian Nursing Research, 2(2), 74-81. https://doi.org/10.1016/S1976-1317(08)60031-6

Mavi Aydoğdu, S. G., \& Karapelit, Z. (2017). Ebelik öğrencilerinin kendi kendine meme muayenesi ile ilgili bilgi ve tutumlarının belirlenmesi. Androloji Bülteni, 19(3), 78-85. doi: 10.24898/tandro.2017.39200

Miller, S. J., O'Hea, E. L., Lerner, J. B., Moon, S., \& Foran-Tuller, K. A. (2011). The relationship between breast cancer anxiety and mammography: experiential avoidance as a moderator. Behavioral Medicine, 37(4), 113-118.
Nacar, G. (2018). Kadınlarda meme kanseri endişe düzeyi ile erken tanı uygulama davranışları arasındaki ilişki. Inönü Üniversitesi Sağlık Hizmetleri Meslek Yüksek Okulu Dergisi, 6(2), 44-53.

Nde, F. P., Assob, J. C., Kwenti, T. E., Njunda, A. L., \& Tainenbe, T. R. (2015). Knowledge, attitude and practice of breast self-examination among female undergraduate students in the University of Buea. BMC Research Notes, 8, 43. https://doi.org/10.1186/s13104015-1004-4

Oladimeji, K. E., Tsoka-Gwegweni, J. M., Igbodekwe, F. C., Twomey, M., Akolo, C., Balarabe, H. S., Atilola, O., Jegede, O., \& Oladimeji, O. (2015). Knowledge and Beliefs of Breast Self-Examination and Breast Cancer among Market Women in Ibadan, South West, Nigeria. PloS One, 10(11), e0140904. https://doi.org/10.1371/journal.pone.0140904

Özer, A., Bankaoğlu, E., Ekerbiçer, H. Ç., Hüdayioğlu, M. R., \& Özdemir, M. (2009). Kahramanmaraş'ta yaşayan bir grup kadının kendi kendine meme muayenesi yapma ve mammografi çektirme durumu ile bunları etkileyen faktörler. Toplum Hekimliği Bülteni, 28, 14-18.

Secginli, S. (2012). Mammography self-efficacy scale and breast cancer fear scale: psychometric testing of the Turkish versions. Cancer Nursing, 35(5), 365-373. https://doi.org/10.1097/NCC.0b013e3182331a9a

Türkmen, H. (2017). Üniversite öğrencilerinin kendi kendine meme muayenesini bilme ve uygulama durumları. Celal Bayar Üniversitesi Sağlık Bilimleri Enstitüsü Dergisi, 4(2), 586-592.

Yılmaz, S., Emre, N., \& Aykota, M. R. (2020). Tıp fakültesi öğrencilerinin meme kanseri ve kendi kendine meme muayenesi ile ilgili bilgi ve tutumlarının değerlendirilmesi. Pamukkale Medical Journal, 13(2), 351-356.

https://doi.org/10.1080/08964289.2011.614291 